\title{
GIANT GROOVES MADE BY CONCENTRATED BASAL ICE STREAMS*
}

\author{
By R. P. Goldthwait \\ (Institute of Polar Studies, Ohio State University, Columbus, Ohio 432 10, U.S.A.)
}

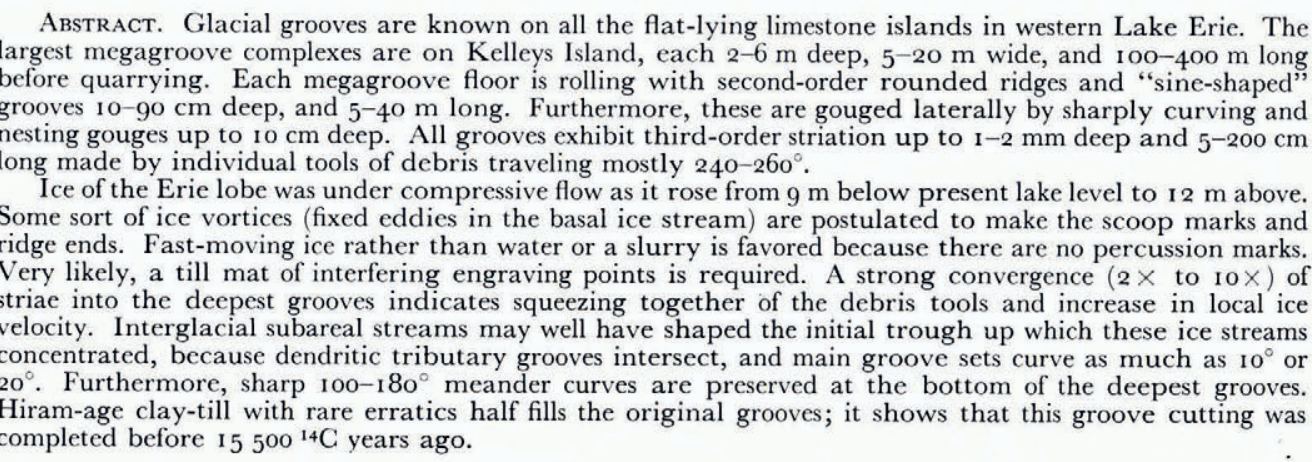

RÉsumÉ. Cannelures géantes et flux concentrés de glace. Les rainures glaciaires sont connues sur toutes les îles plates calcaires de l'Ouest du Lac Érié. Les plus grands complexes de grandes cannelures de Kelleys Island ont 2 à $6 \mathrm{~m}$ de profondeur, 5 à $20 \mathrm{~m}$ de largeur et 100 à $400 \mathrm{~m}$ de longueur avant de déboucher. Le plancher de chaque grande cannelure est ondulé par des striures "sinusoïdales" de second ordre de 10 à $90 \mathrm{~cm}$ de profondeur et de 5 à $40 \mathrm{~m}$ de longueur. En outre, elles sont creusées latéralement par des rigoles à bords aigus et emboîtées allant jusqu'à $10 \mathrm{~cm}$ de profondeur. Toutes les cannelures montrent des stries de troisième ordre jusqu'à I ou $2 \mathrm{~mm}$ de profondeur et 5 à $200 \mathrm{~cm}$ de longueur, creusées par des "outils" individuels de débris morainiques voyageant dans la direction de 240 à $260^{\circ}$.

Le lobe de glace Érié était soumis à un écoulement compressif lorsqu'il s'élevait depuis $9 \mathrm{~m}$ en dessous du niveau actuel du lac jusqu'à $12 \mathrm{~m}$ au-dessus. Il faut admettre quelques vortex de glace (tourbillons fixes dans le courant de fond de glace) pour expliquer les traces de creusement. Une glace à mouvement rapide plutôt que de l'eau ou un éboulement est à mettre en cause parce qu'il n'y a pas de trace de choc, seulement une longue strie. Très probablement, il faut admettre un tapis morainique de blocs pointus graveurs enchevêtrés. Une forte convergence $(2 \times$ à $\mathrm{IO} \times)$ des stries dans les cannelures les plus profondes indiquent qu'il y a eu accumulation des débris morainiques servant d'outils et accroissement de la vitesse locale de la glace. De petits cours d'eau interglaciaires peuvent bien avoir formé la rigole initiale que ces courants de glace, concentrés à cause des cannelures dues aux apports dendritiques, recoupent, les cannelures principales présentent des courbures allant jusqu'à 10 ou $20^{\circ}$, des méandres très aigus avec courbes de 100 à $180^{\circ}$ furent conservés dans le fond des cannelures les plus profondes. De l'argile morainique de l'âge d'Hiram avec de rares blocs erratiques ont rempli à moitié les cannelures initiales: ce qui montre que le découpage des cannelures était achevé il y a plus de 15500 ans ${ }^{1+C}$.

Zusammenfassung. Grossrinnen und konzentrierte Eisströme. Glaziale Rinnen sind auf allen flachgelagerten Inseln im westlichen Eriesee bekannt. Die ausgeprägten Grossrinnenkomplexe auf Kelleys Island waren 2 bis $6 \mathrm{~m}$ tief, 5 bis $20 \mathrm{~m}$ briet und $\mathrm{r}$ oo bis $400 \mathrm{~m}$ lang, bevor sie als Steinbrücke genutzt wurden. Der Boden jeder Grossrinne ist durchsetzt von sekundären "sinusförmigen" Rinnen von Io bis $90 \mathrm{~cm}$ Tiefe und 5 bis $40 \mathrm{~m}$ Länge. Ausserdem sind sie seitlich ausgehöhlt durch engkurvige und ineinandergreifende Meisselrillen bis $10 \mathrm{~cm}$ Tiefe. Alle Rinnen zeigen eine tertiäre Riefelung bis $\mathrm{I}$ oder $2 \mathrm{~mm}$ Tiefe und 5 bis $200 \mathrm{~cm}$ Länge, erzeugt durch einzelne Griffel des Schuttes, der meist $240-260^{\circ}$ wanderte.

Das Eis des Erie-Lobus befand sich in kompressiven Fliessen, als es von $9 \mathrm{~m}$ unter dem heutigen Seespiegel auf $12 \mathrm{~m}$ darüber anstieg. Zur Erzeugung der Aushöhlungen muss eine Art von Eiswirbeln (feste Strudel im Eisstrom am Untergrund) angenommen werden. Schnell bewegtem Eis wird der Vorzug vor Wasser oder einer Zementbrühr gegeben, weil keine Schlagspuren zu finden sind, lediglich lange Riefen. Sehr wahrscheinlich war eine Schuttmatte mit darin eingeschlossenen Gravierspitzen erforderlich. Eine starke Konvergenz (2- bis 1o-fach) der Riefen in die tiefsten Rinnen deutet auf eine Zusammendrängung der Schuttwerkzeuge und auf eine Zunahme der lokalen Eisgeschwindigkeit hin. Kleine Ströme im Eis könnten den ursprünglichen Trog ausgeformt haben, auf den sich diese Eisströme dann konzentrierten, weil baumförmige tertiäre Rinnen kreuzen, die Schar der Hauptrinnen Kurven bis zu $\mathrm{IO}^{\circ}$ oder $20^{\circ}$ ausführt und in den tiefsten Rinnen scharfe Mäanderkurven von $100^{\circ}$ bis $180^{\circ}$ erhalten sind. Tonablagerungen der Hiram-Zeit mit wenigem Geschiebe füllten die ursprünglichen Rinnen zur Hälfte; daraus folgt, dass das Einschneiden der Rinnen bereits vor $15500{ }^{1+C}$ Jahren abgeschlossen war.

* Contribution No. 362, Institute of Polar Studies, Ohio State University, Columbus, Ohio 432 1 o, U.S.A. 


\section{HISTORIC INTRODUCTION}

The spectacular grooves crossing the gentle stoss slope and broad crest of Kelleys Island in western Lake Erie (Fig. I) have evoked "theories of formation" from many geologists since 1840. Quarrying of the uniform pure limestone (Middle Devonian; Columbus Formation), in which they were engraved, started in 1833 and dwindled to small-holding operations after World War I. This provided long-continued rock exposures but it destroyed all large surface grooves except one beautiful example near the North Bay (west-north-west) of the island

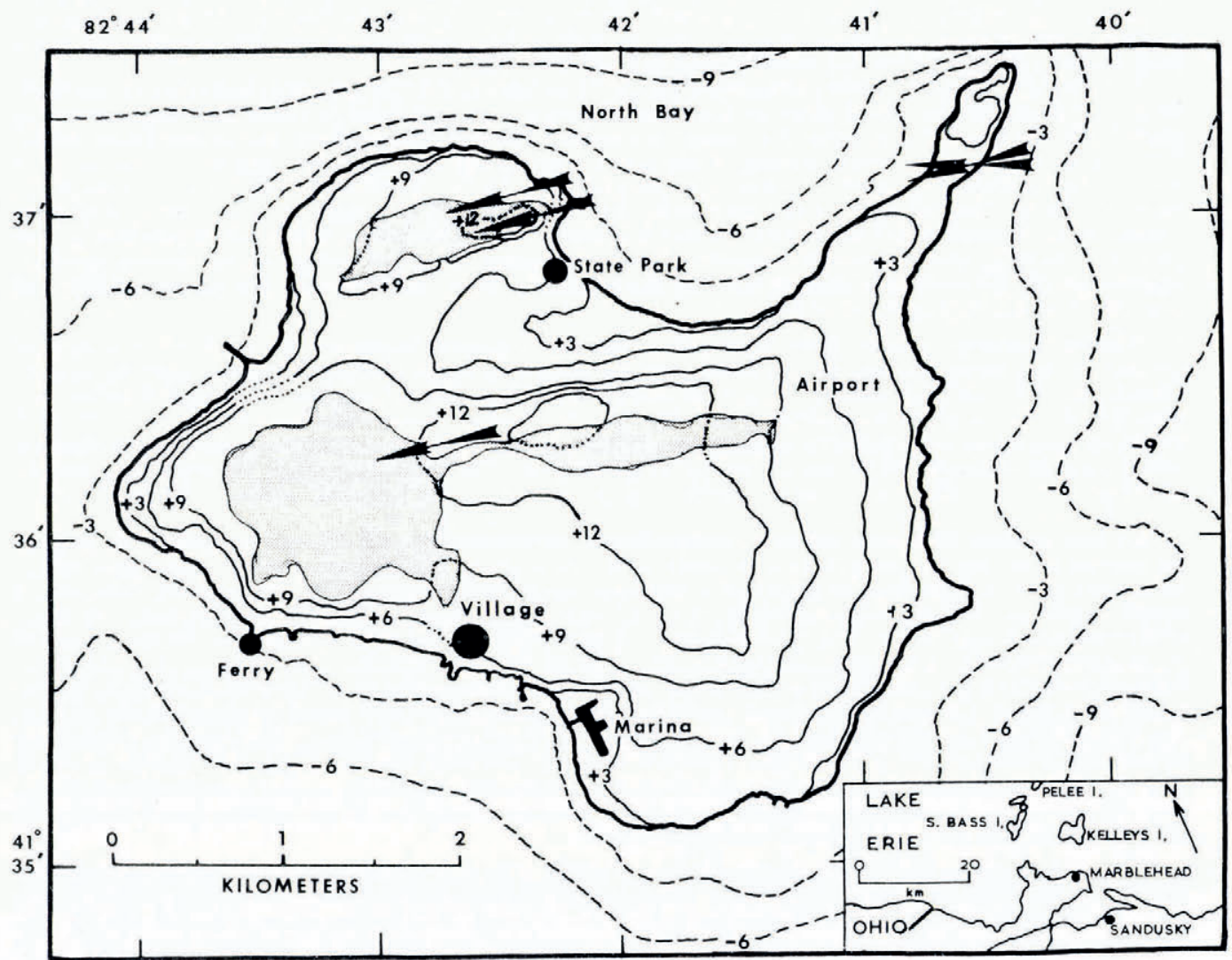

Fig. I. Contour map of Kelleys Island, Ohio, based on the U.S. Geological Survey's 1959 $7 \frac{1}{2}$ minute quadrangle. Contour interval $3 \mathrm{~m}$ by interpolation. Shaded zones show where quarrying removed grooves or striae. Glacial movement arrows are shown where the lakeside end of "Great Groove" and the remaining groove at Glacial Grooves State Park reached North Bay. In the center lesser grooves are re-buried. The arrows on the north-east shore show two sets of striae common to the smooth limestone surface all along that east shore.

(Fig. I). This was given to the State of Ohio in 1925; but it was not fully exposed until recently (1972-73) by the Ohio Historical Society through one of its benefactors and geology student labor from Ohio State University.

The earliest theorists used terms such as "diluvial boulder action" because the flood idea died slowly. Then G. K. Gilbert (1873), N. H. Winchell (1873), Charles Whittlesey (1879), and T. C. Chamberlin (1888) all expressed clear glacial origins. The striae in all parts of the grooves, plus the eastern and northern erratics in the filling till, and the up-hill sweep of 
striae have convinced most skeptics of this. However, Gilbert was impressed by the "smoothed pits and bowls", so he postulated water falling through the thick ice. Since 1959, with the discovery of water deep below thick $(2000 \mathrm{~m})$ and cold continental ice, many aspects of the water hypotheses have been reviewed. What did happen to that basally melted water from ice which lasted at least $10000{ }^{14} \mathrm{C}$ years over this area? Could a slurry of glacial till and melt water under very high pressures produce these smooth up-hill gouges?

These are not the only glacial grooves in the world, although they once were titled "the largest". A larger area of more drumlinoid forms was discovered in air photographs of a comparable limestone terrain in northern MacKenzie Valley (Smith, 1948). Most grooves in intensively glaciated areas are like the single or second-order grooves here (Gjessing, 1966). Each flute is explainable or related to a weak rock zone (concentrated groove) or a rock hard to abrade (sheltered ridge). Not so here.

This whole western Lake Erie area is prone to glacial fluting. There are secondary grooves and ridges nearly as deep $(1 \mathrm{~m})$ on the mainland near the top of Marblehead Peninsula $7.5 \mathrm{~km}$ to the south-south-west, and south of Put-in-Bay on South Bass Island, I I km west-north-west, or $14 \mathrm{~km}$ north near the south end of Pelee Island (Fig. I). All are $240-260^{\circ}$ except on Pelee Island where they are nearer $270^{\circ}$. All are in uniform Columbus limestone that crops out as a band $10 \mathrm{~km}$ wide from these islands south through central Ohio. Here it stands $24 \mathrm{~m}$ above the fissile shale lake bottom of the Erie Basin. Clearly, these are associated with the broad compressional rise of ice out of the Lake Erie Basin over a uniform limestone rock vulnerable to deep carving.

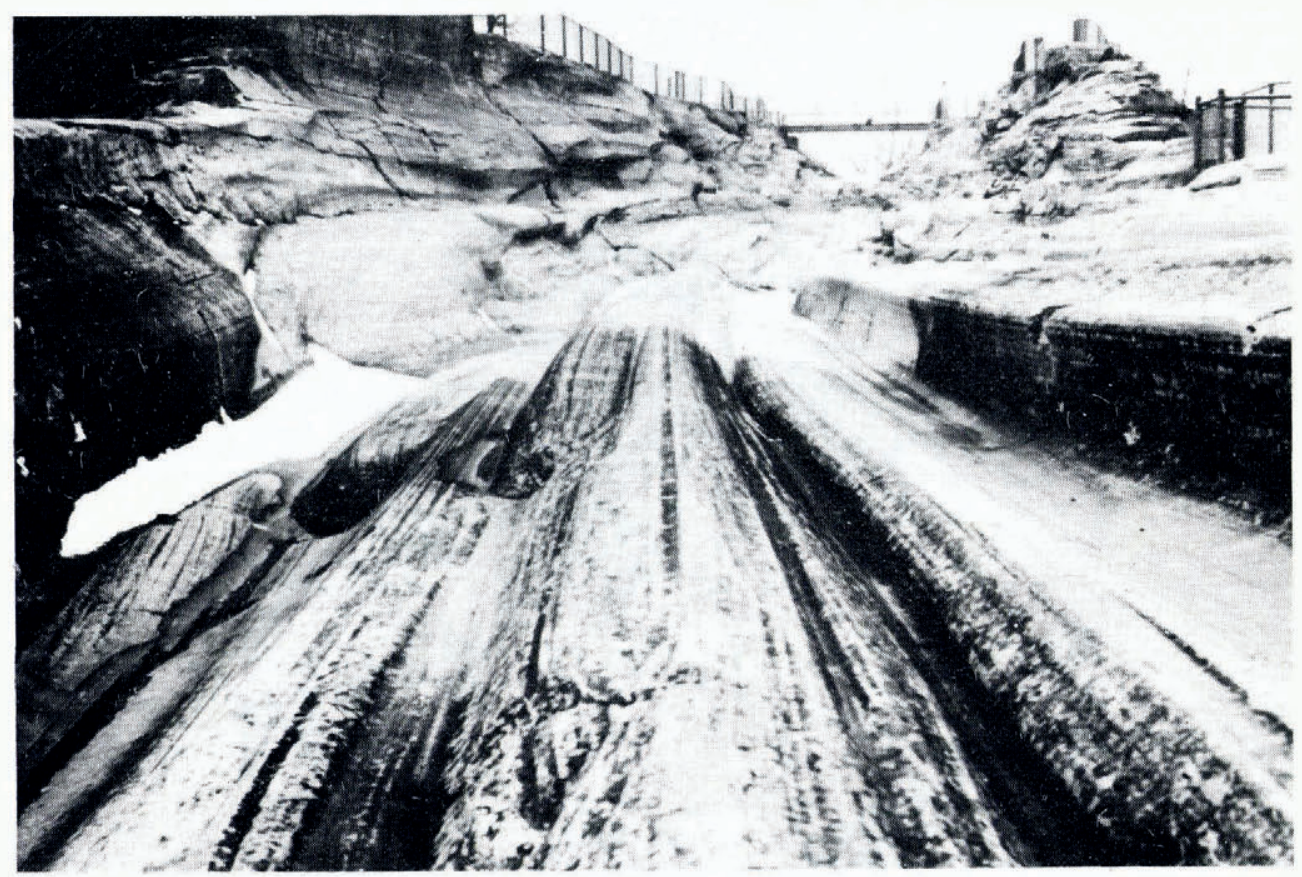

Fig. 2. Megagroove with "sine" grooves. Looking west in the direction of inferred ice flow at Glacial Grooves State Park, Kelleys Island. The second-order sculpture shows both grooves and rounded ridges, I0-9o cm in amplitude, described by Carney (I9IO) as "Corinthian columns stacked side by side". Note the overhang on the right and the decided bend in the grooves in mid picture. The dark foreground was the original "park" exposed early this century; the long lighter stretch beyond was dug out in 1972. 
MeAningful DEsGription

The giant grooves on Kelleys Island consist of four size orders of abrasion:

I. Each megagroove itself is or was 5-20 $\mathrm{m}$ wide and $\mathrm{I}^{-00-400} \mathrm{~m}$ long. Between megagrooves and throughout the limestone region there is mostly a smooth flat striated rock surface under till. The deepest central points in each megagroove, however, are 2-6 m below this smooth surface. The one megagroove left in the Glacial Grooves State Park is I $30 \mathrm{~m}$ long (Fig. 2) but old pictures show that it extended both $50 \mathrm{~m}$ farther west (at I 2-I 5 m elevation above Lake Erie) and $100 \mathrm{~m}$ east down to lake level. At least one parallel adjacent groove was found buried just south of this by borings (C. W. Albrecht) and geophysics (H. C. Noltimeier). Others to the north, including the "Great Groove", were quarried away. Measurements of azimuths over the years vary between $240^{\circ}$ and $260^{\circ}$. The megagrooves do curve up to $20^{\circ}$.

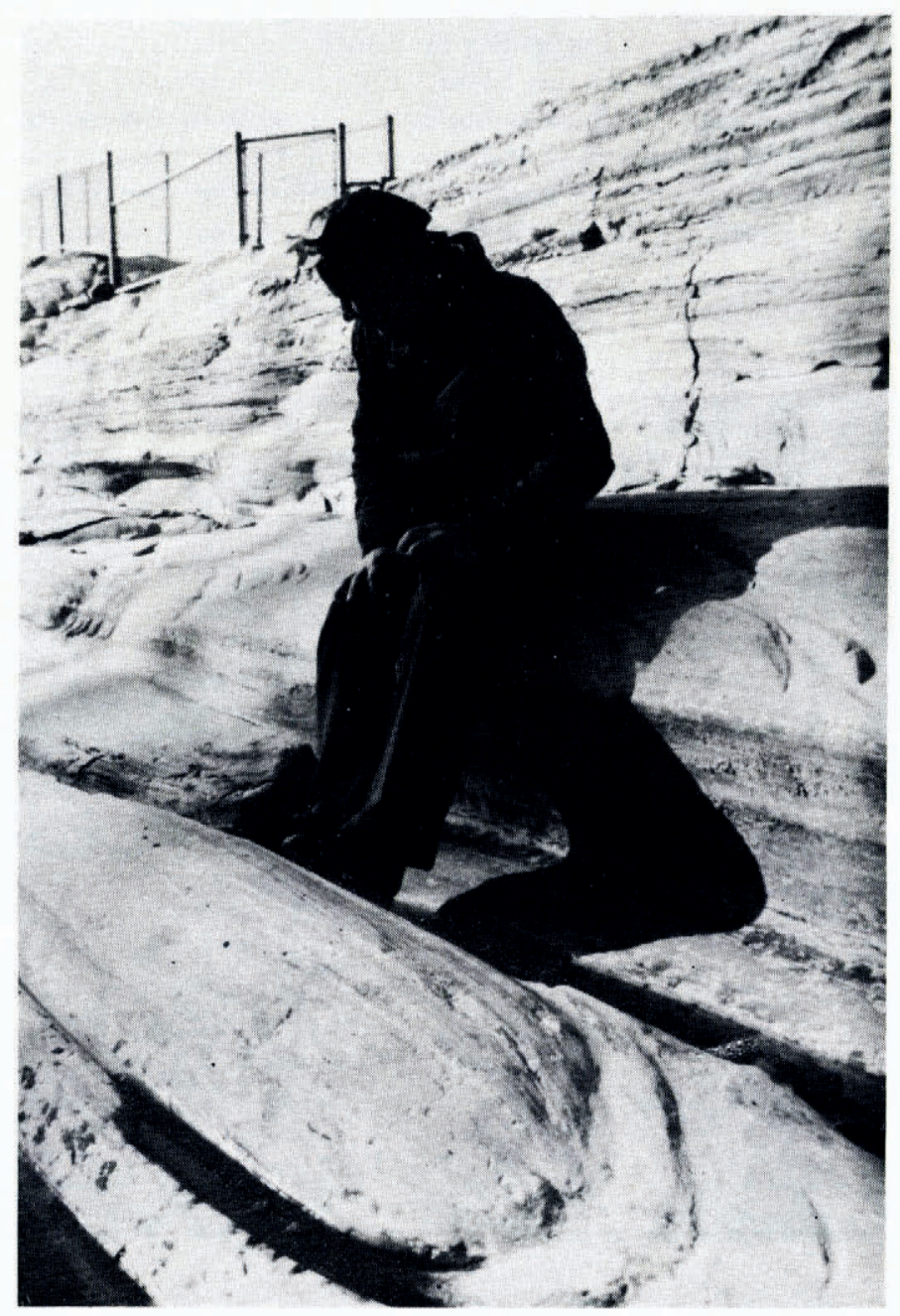

Fig. 3. Scoop marks at the head of a "sine" ridge, Kelleys Island, November 1976. Isolated scoops and undercutting to the right and left of Dr Y. Lavrushin. Others in the lower right wrap around the stoss ridge end. Third-order striae radiate (diverge) up over the ridge. Corals are visible faintly in the ridge head. 
2. The floor of each megagroove consists of 5-9 second-order sub-grooves or "sine" grooves. They are separated by rounded ridges which form a "sine" curve in cross-section (Fig. 2). The individual second-order grooves and ridges are $10-90 \mathrm{~cm}$ in amplitude and extend 5-40 $\mathrm{m}$ along the megagroove floor, but never the full length of any megagroove. These ridges are interrupted, gouged on the sides and even cut off, by sweeping smooth lateral depressions at azimuths up to $070^{\circ}$ or $090^{\circ}$ across the megagroove trend. Early literature called them "scoop marks" (Fig. 3).

3. All over the "sine"-groove floor, sides, and ridges there are striae and other individual tool-point marks usually a millimeter or two wide but up to a centimeter wide in places. These third-order striae are about $\mathrm{I} \mathrm{mm}$ deep. They are commonly traceable for IO-IOO cm (Figs 3 and 4). They mark the path of the last large tool over that line of surface.

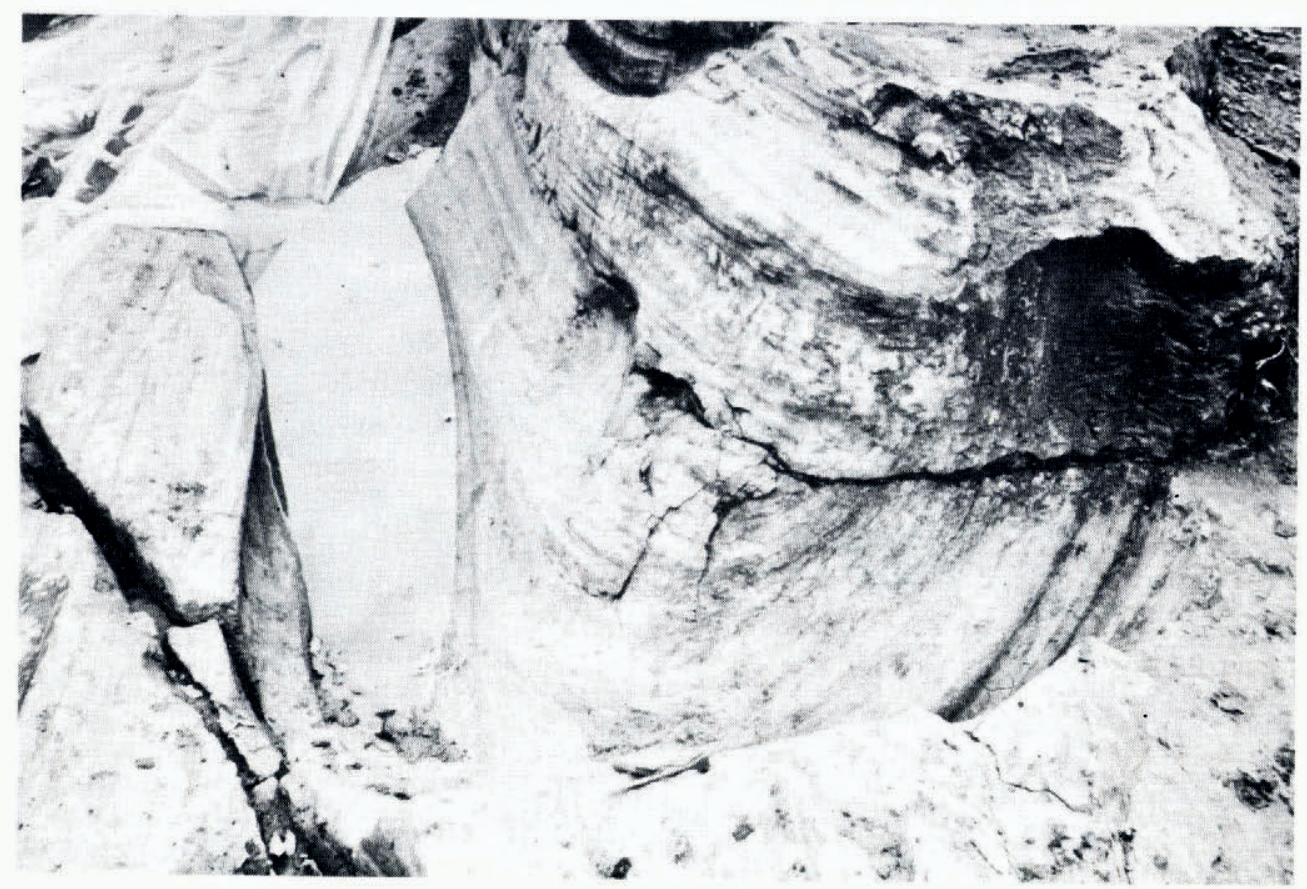

Fig. 4. Vertically descending gouge with striae, Kelleys Island, May 1972. This truncates small grooves and ridges in the upper right but it joins and deepens a "sine" groove in the main trend to the west (left center). A plastic cover was used in the upper left to try to preserve the high polish during the first winter of exposure.

4. A high gloss or polish is typical of many glaciated surfaces in quarries through central Ohio, wherever post-glacial solutions have not pitted or roughened rock surfaces under till. Alternatively, some are encrusted with calcium carbonate re-deposited from the till above. Actually, when first uncovered, the glacial grooves, i.e. the Glacial Grooves State Park, had a high gloss or patina which rapidly dulled in a year and chipped off in flakes and grains within 5 years (Fig. 4). Since this gloss can be produced artificially in rock polishing machines using fine rouge powder, and since a clay-till did partially fill each groove, it is deduced that the fine clays of the till matrix did this polishing. 


\section{SOME DEDUCTIONS FROM SECOND-ORDER RIDGES}

The second-order "sine" ridges are cut away on their sides in many places by all kinds of smooth curved gouges, which also bear some third-order tool-made striae inside. In other words, the scraping tools swept into each curved gouge after the "sine" ridge was essentially formed. This is the last destructional event under ice because gouges sharply cross-cut the uniform ridges (Fig. 3). This action lasted long enough and was vigorous enough to make gouges $\mathrm{I}-\mathrm{I} O \mathrm{~cm}$ deep.

Figure 4 shows a large gouge produced by a vertically descending current of ice or slurry. Such a gouge broadens and its striations curve westward always into the trend of the megagrooves. This shows that the tools were swept along finally in the general flow of the ice or slurry. From the length of the striae and absence of percussion marks, we may deduce that the moving agent was a very viscous plastic; it held its tools in a firm grip for many centimeters.

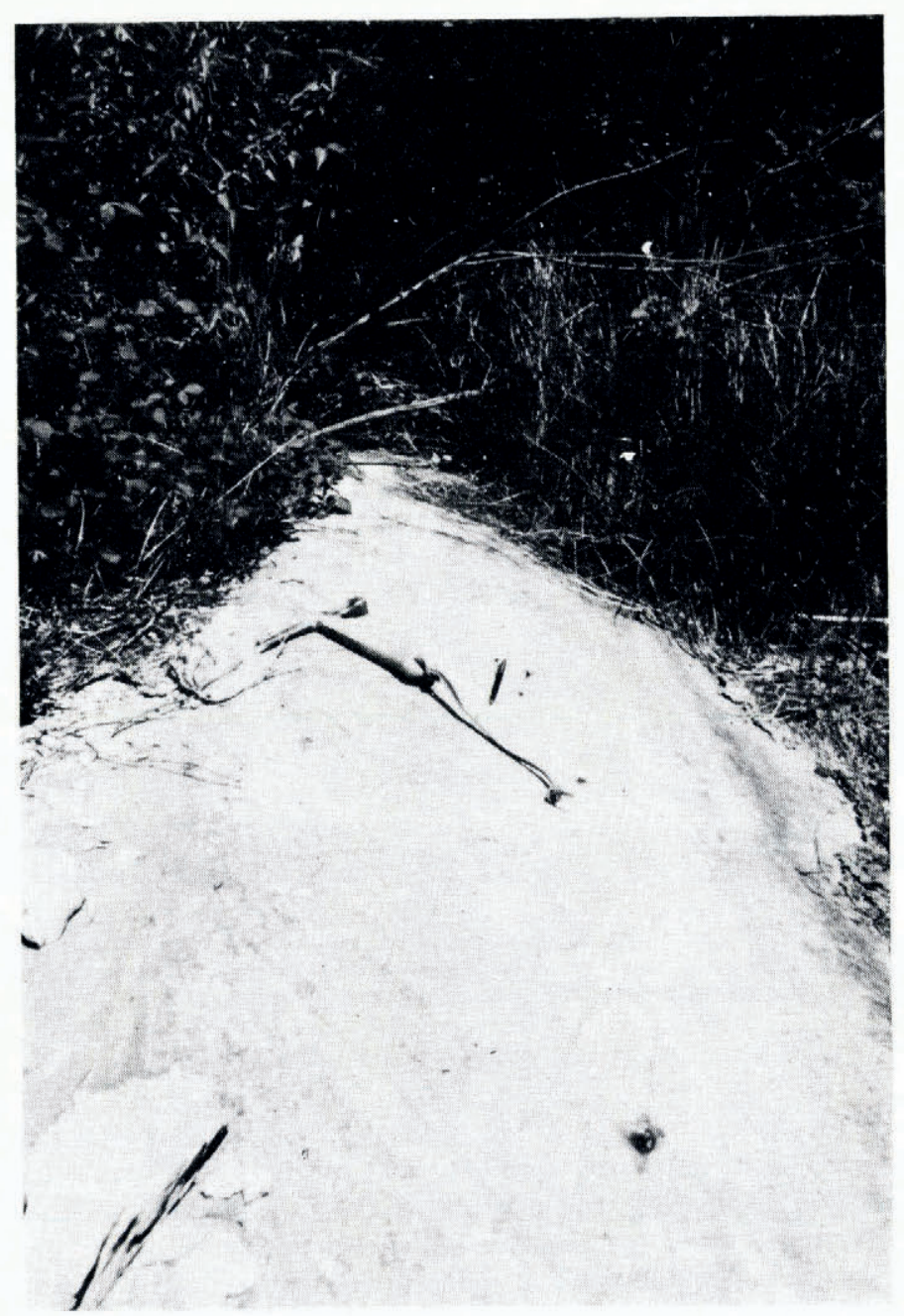

Fig. 5. Criss-crossing striae on the tail "down-glacier" end of one "sine" ridge, just east of the West Quarry in central Kelleys Island. Striae "climb" out of the grooves on the right and left and cross near the pen and pick handle. $(25 \mathrm{~cm}$ long). The rounded ridge becomes lower in the foreground (bottom). 
Some mix of ice near its pressure-melting point, and angular rock debris with hard "tool" points, fits the requirements of basal abrasion better than a water and mud slurry unless the latter is conceived of as sticky and thick.

The head ends of the second-order sine-shaped ridges, as seen from the easterly (down-hill) direction, look like the end of a large half water melon or a huge half-cigar (Fig. 3). Thirdorder engraved striae radiate up over it and especially around either side into the associated narrower grooves. In fact, the second-order grooves are sharpest, narrowest, and deepest where many striae converge just east of the head of a ridge. This convergence into troughs suggests that 2-Io times as much debris-armed ice or slurry passed through each deep local groove position as rose along adjacent ridges. This can only mean 2-10 times the velocity; if the main ice moved 5-10 $\mathrm{m} / \mathrm{d}$ at the surface, * these might well have moved or "squirted", more than $10-100 \mathrm{~m} / \mathrm{d}$ or $7 \mathrm{~cm} / \mathrm{min}$. These were concentrated local streams just at the sole of the glacier.

This deduction of basal lateral concentrations of tools is born out by the up-hill or tail end of some second-order "sine" ridges as well. In all cases the ridge decreases in amplitude (lowers gradually) in I0-40 m. The individual tool striae in adjacent grooves "climb" gradually up on to the ridge from the sides, even criss-crossing striae from the other side (Fig. 5). In other words, the redistribution of engraving tools takes place $10-40 \mathrm{~m}$ down-glacier. Fast-moving ice or slurry must dilate and the ridge flattens out where erosion evens out. Presumably, the speed of basal slip becomes uniform too.

Symmetrical with the sharp rounded stoss end of some ridges are a series of sharp curved gouges I-IO cm deep and 10-50 cm long (Fig. 3). They outline the ground plan of the "water-melon structure" 20-100 cm "ahead" of its position, and they "nest" around it. These suggest a possible retrogression of the down-hill head end of the water-melon ridge as vigorous abrasion of oncoming ice or slurry rounded it off.

\section{HYPOTHESES FOR THE FORMATION OF "SINE" RIDGES}

No one feature of the grooves causes more speculation than the secondary ridges; why are there any "water-melon ends" giving rise to rounded ridges at all? T. Hughes (unpublished manuscript) first proposed plucking by the ice along natural joints. This Devonian limestone is systematically and broadly jointed with the principal system nearly vertical but cutting diagonally across the grooves $\left(315^{\circ}\right.$ and $\left.045^{\circ}\right)$. Any thick plucked blocks, especially on a protruding high and facing oncoming ice, could deflect currents of ice or slurry to either side to initiate the bordering trenches. The blunt end would become rounded and recede. It may be assumed that basal motion is by plastic deformation rather than regelation of features so large.

Many students in class visits from 1947 to 1977 suggest that a large erratic traveling in the basal ice became wedged crosswise in some narrower parts of uniform "sine" grooves. The plastic ice-debris mix (or slurry of till) swirled around and under the boulder, concentrating scour in gouges and narrow grooves, but leaving a ridge in the protected area behind the boulder. However, during excavation of about $250 \mathrm{~m}^{3}$ of till from the groove in the Glacial Grooves State Park, a total of only 203 stones could be found, and not one was big enough to be wedged crosswise.

Shaw and Freschauf (1973) turned to kinematic waves or helical turning of the basal ice to form some secondary ridges. Certainly, where the rounded ridges are systematic and uninterupted, as at the long-exposed east end of Glacial Groove State Park (Fig. 2) one can envision a very regular longitudinal standing wave parallel to motion.

\footnotetext{
* Common in Antarctic and Greenland ice streams (Cameron, 1965).
} 
Lavrushin and Goldthwait (1978), in reviewing this locality, came back to one of the earliest suggestions, viz. that the ridge ends must be of harder "less-scratchable" rock. In most glaciated areas, such as Baffin Island, Alaska, Greenland, and Spitsbergen, the lesser ridges $10-100 \mathrm{~cm}$ wide arise where a tougher lithology has been abraded severely and stands up. Here a number of careful early workers denied any difference in "hardness" from ridge to groove. Yet we found most of the water-melon ends are full of Zaphrentis corals. Conceivably, under pressures of nearly 100 atmospheres, this coralline form of calcite was slightly more resistant to abrasion.

Hallet (1976) introduced a new possible factor. Water abrasion had often been considered, and certainly the creation of water, where the ice sole must be at the pressure-melting point, is a well-accepted glaciological principle. However, solution of limestone to calcium bicarbonate might be a new factor under ice, notably on compressional slopes. But the corollary, which is calcite deposition on the lee slopes to westward of the ridges, has not been demonstrated here. Could it occur in such large-scale gross topography?

\section{HYPOTHESES FOR CONCENTRATION OF EROSION INTO MEGAGROOVES}

Few if any observing geologists over the last century would argue that the megagrooves were not at least partly glacial in origin; the surface is completely scored with long striae, whose azimuth is down the length of Erie Basin, and all recorded grooves were at least halffilled with till, bearing erratics from eastern Ontario, and perhaps New York.

There is abundant evidence, however, that all major grooves were located in former small stream courses which flowed eastward down the dip of Columbus limestone (VerSteeg and Yunck, 1935). Presumably, these were interglacial karst stream courses (lapies). Some evidence was more explicit during quarrying (Fig. 6); there were sharp meanders and plunge basins at the deepest parts of each megagroove. One small "meandering section" is still preserved near the middle of Glacial Grooves State Park. This is why Gilbert (1873) seized upon moulins from water falling through the thick ice as an explanation for their origin.

Other compelling evidence that these were once stream courses is that some show shallower side megagrooves entering in dendritic pattern at angles of $10-25^{\circ} *$ And all megagrooves bend $5^{-10^{\circ}}$ as one looks down their axes (Fig. 2). In other words, the basal glacier ice or slurry was deflected in crooked channels with pre-existing tributary courses. This was a local streaming into local creek beds climbing up to the crest of the broad rock divide. These were not the broad streams of surface ice such as described in Vanderford Glacier (Cameron, 1965) in Antarctica.

Altogether, this makes for a compressional situation where basal ice near $0^{\circ} \mathrm{C}$ at minimum viscosity accelerated to pass over a restriction much as in Carol's (1947) roche moutonnée observations. Locally, volume of ice discharge at the base of the glacier probably exceeded the discharge rate near the ice surface of the glacier. T. Hughes (unpublished manuscript) suggested that this is a concentrated kinematic instability likely over large ice-covered bed projections, where the basal temperate $\left(0^{\circ} \mathrm{C}\right)$ ice layer reduces to zero thickness at the highest sites; so the ice freezes on to these highest points (Lliboutry, I966).

\section{Time AND THickNesS OF ICE SHEET INVOLVED}

Many studies of tills, both in southern Ontario north of Lake Erie (Dreimanis and Reavely, 1953) and east from Cleveland (White, 1960), define one widespread late Wisconsinan-age till, the Port Stanley or Hiram till. C. C. Rich (unpublished studies) found that it also covers earlier tills in north-western Ohio. Little, if any, sliding abrasion can accompany deposition

\footnotetext{
* Seen now at the northwesternmost foot-bridge crossing in Glacial Grooves State Park.
} 


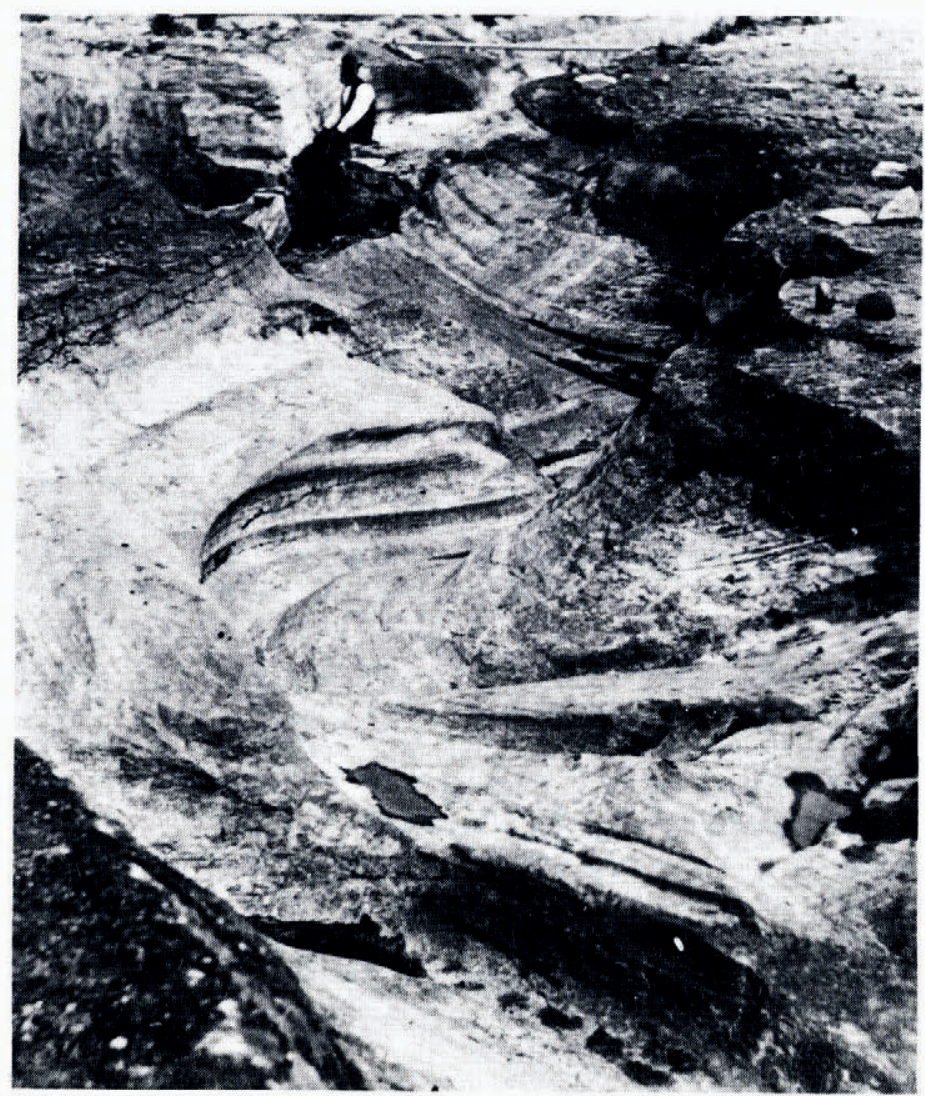

Fig. 6. Meandering megagroove base. An 1875 photograph of one groove quarried away. North Quarry of Kelleys Island, probably north-west of Glacial Grooves State Park. (This is one of the many original photographs at the Historical Society and Orton Museum, Columbus, Ohio.)

of such compact till, so megagrooves and "sine" grooves must precede it. Muskopf (unpublished) made a careful study of the compact till which half-filled the megagroove excavated in 1972 , and found it identical to the Hiram till in clay content $(35-40 \%)$, carbonate content $\left(2 \mathrm{I}-25 \frac{1}{2} \%\right)$, and brown color $(7.5 \mathrm{YR} 4 / 4)$. It is similar in type of clay $(68 \%$ illite, $27 \%$ vermiculite) and in stone count. So, the grooves were completed before this re-advance of ice covered northern Ohio, which came after the Erie interstade $15500{ }^{14} \mathrm{C}$ years ago (Dreimanis and Goldthwait, I975).

In Glacial Grooves State Park and in the giant grooves excavated last century, the Hiram till was covered by $5^{-80} \mathrm{~cm}$ of laminated fine sands and coarse silts. This is interpreted as lacustrine sediment and is common to all the western basin, less than $70 \mathrm{~m}$ above Lake Erie. In the western two-thirds of the Lake Erie Basin, glacial lakes Maumee, Arkona, Whittlesey, Warren, and Wayne are demonstrated to have had water surfaces well above the highest parts of all islands in western Lake Erie. All lakes, especially the last two, left silts. Radiocarbon dates of I $3600-11300$ years* apply to all these except the first (Maumee) stage. The weathering and pitting of the upper groove walls began when ice dams disappeared and water receded to a level lower than today, which was no later than I I ooo years ago.

* The three youngest dates are disputed by evidence at Toronto, Niagara Falls, and Buffalo. 
The till itself, both in the grooves and in the region, is fresh and unleached. The deepest leaching is hardly $60 \mathrm{~cm}$ in soils of well-drained tills in the region. The surface of the bedrock beneath the till is fresh, polished, and unleached, whether buried 0.5 , I, or $2 \mathrm{~m}$ deep. Such thin soils in drift and fresh bedrock never characterize any penultimate (Illinoian) glaciated area, so these grooves were at least freshened and finished within the late Wisconsinan glaciation. The invasion of the last ice is generally dated by lacustrine and organic deposits, which were over-run at Garfield Heights, Toledo, and Port Talbot about 24 000-25 0oo years ago (Dreimanis and Goldthwait, 1975). The glacial grooves could have been shaped out of pre-glacial stream beds anytime between 24000 and ${ }_{1} 5000{ }^{14} \mathrm{C}$ years ago.

Possibly some surface abrasion occurred during all these 8500 years. At $1 \mathrm{~mm} / \mathrm{year}$, ${ }^{*}$ this might even have accomplished the whole job. But most visiting geologists, impressed with the magnitude of the erosion, have suggested that the bulk of the erosion was during the $45^{\circ 0}$ years of thickest ice, a period lasting from $2 \mathrm{I} 500$ to $17000{ }^{14} \mathrm{C}$ years ago (Dreimanis and Goldthwait, 1975). Early in a long glacial cycle is an unlikely time for erosion as the ground is often deeply frozen during cold summers of ice advance and ice is inferred to be everywhere frozen to its base (Goldthwait, [ ${ }^{\mathrm{c}}{ }_{1973}$ ). There is no basal slip. It takes centuries for Earth heat to drive the zero isotherm up to the base of the glacier once it covers frozen land. Any turbulence that may produce the second-order swirling cuts has never been observed in erosion near existing glacier margins nor in tunnels up to $400 \mathrm{~m}$ back from the ice edge (Goldthwait, I96o).

If Greenland and Antarctica are representative examples, the actual depth of ice $300-500 \mathrm{~km}$ back from the Wisconsinan ice margin was at least $\mathrm{I} 500$ to $2000 \mathrm{~m}$; and these may be conservative depths if one postulates a peripheral snow-feeding center over the Lake Erie Basin. Does such visco-plastic ice with any mix of debris, under the confining pressures of $\mathrm{I}$ oo bar and at its pressure-melting point, have any properties which allow it to gouge out pure limestone? Hence the jetting action appears to be generated by vortices set into motion by the deep meandering topography of rather small pre-glacial valleys.

\section{REFERENGES}

Boulton, G. S. [ ${ }^{\mathrm{c}}$ I974.] Processes and patterns of glacial erosion. (In Coates, D. R., ed. Glacial geomorphology. Binghamton, N.Y., State University of New York, p. 41-87. (Publications in Geomorphology.))

Cameron, R. L. I965. The Vanderford submarine valley, Vincennes Bay, Antarctica. (In Hadley, J. B., ed. Geology and paleontology of the Antarctic. Washington, D.C., American Geophysical Union, p. 21 I- 16 . (Antarctic Research Series, Vol. 6.))

Carney, F. 1910. Glacial erosion on Kelleys Island, Ohio. Bulletin of the Geological Society of America, Vol. 20, p. 640-45.

Carol, H. 1947. The formation of roches moutonnées. Journal of Glaciology, Vol. I, No. 2, p. 57-59.

Chamberlin, T. C. 1888. The rock-scorings of the great ice invasion. U.S. Geological Survey. 7th Annual Report, $1885-86$, p. $147-248$.

Dreimanis, A., and Goldthwait, R. P. 1975. Wisconsin glaciation in the Huron, Erie, and Ontario lobes. Geological Society of America. Memoir 136, p. 71-106.

Dreimanis, A., and Reavely, G. H. 1953. Differentiation of the lower and upper till along the north shore of Lake Erie. Journal of Sedimentary Petrology, Vol. 23, No. 4, p. 238-59.

Gilbert, G. K. 1873. Surface geology of the Maumee valley. Geological Survey of Ohio. Report, Vol. I, p. 539-40.

Gjessing, J. 1966. On 'elastic scouring' and 'subglacial erosion'. Norsk Geografisk Tidsskrift, Bd. 20, Ht. 1-2, 1 $965-66$, p. $1-37$.

Goldthwait, R. P. I 960 . Study of ice cliff in Nunatarssuaq, Greenland. U.S. Snow, Ice and Permafrost Research Establishment. Technical Report 39.

Goldthwait, R. P. [ [ ${ }^{\mathrm{r}}$ g73.] Till deposition versus glacial erosion. (In Fahey, B. D., and Thompson, R. D., ed. Research in polar and alpine geomorphology. Proceedings: 3 rd Guelph Symposium on Geomorphology, 1973. Norwich, University of East Anglia, Geo Abstracts Ltd.; Guelph, Ontario, University of Guelph, Dept. of Geography, "Geomorphology Symposium", p. 159-66.)

Hallet, B. I976. Deposits formed by subglacial precipitation of $\mathrm{CaCO}_{3}$. Geological Society of America. Bulletin, Vol. 87 , No. 7 , p. 1003-15.

* A near-margin erosion-rate recently measured (Boulton, $\left[{ }^{\mathrm{C}}{ }_{1974}{ }{ }\right)$. 
Lavrushin, Yu., and Goldthwait, R. P. 1978. Krupnaya ekzaratsionnaya rytvina o. Kelli (oz. Eri), yeye proiskhozhdeniye i mikrorel'yef [Large exaration trough at Kelleys Island (Lake Erie), its origin and microrelief]. Geomorfologiya, 1978, No. 2, p. 79-84.

Lliboutry, L. A. 1966. Bottom temperatures and basal low-velocity layer in an ice sheet. Fournal of Geophysical Research, Vol. 71, No. 10, p. 2535-43.

Muskopf, J. Unpublished. Studies of till from Kelley's Island, Ohio. [B.Sc. thesis, Ohio State University, I973.]

Shaw, J., and Freschauf, R. C. 1973. A kinematic discussion of the formation of glacial flutings. Canadian Geographer, Vol. I 7, No. I, p. 19-35.

Smith, H. T. U. 1948. Giant glacial grooves in northwest Canada. American Journal of Science, Ser. 4, Vol. 246, No. 8 , p. 503-1 4 .

VerSteeg, K., and Yunck, G. 1935. Geography and geology of Kelley's Island. Ohio fournal of Science, Vol. 35 , No. 6 , p. $42 \mathrm{I}-33$.

White, G. W. I960. Classification of Wisconsin glacial deposits in northeastern Ohio. U.S. Geological Survey. Bulletin I 2 I-A.

Whittlesey, C. 1879. Ancient glacial action, Kelly's Island, Lake Erie. Proceedings of the American Association for the Advancement of Science, Sect. B, Vol. 27, p. 239-45.

Winchell, N. H. I873. The surface geology of north-western Ohio. Proceedings of the American Association for the Advancement of Science, Sect. B, Vol. 2 1, p. $152-86$. 